\title{
IHWAL PENERAPAN HUKUM ISLAM DI INDONESIA
}

\author{
Ines Romadona Aditya Putri, Ashif Az Zafi \\ Institut Agama Islam Negeri Kudus, \\ J1. Conge Ngembal Rejo PO BOX 51, Kudus, Jawa Tengah, Indonesia \\ Email: inesromadhona2@gmail.com, ashifazzafi@iainkudus.ac.id
}

\begin{abstract}
ABSTRAK
Penyusunan syariat Islam di Indonesia mengalami kendala sejak mulai masuknya hukum Barat ke Indonesia. Sehingga beberapa teori hukum lahir sebagai tanggapan atas gesekan antara hukum Barat dan hukum Islam. Teori resep merupakan salah satu strategi Belanda untuk mendiskreditkan dan mereduksi hukum Islam yang berlaku di Indonesia. Kemudian muncullah teori Exept law Exit dan Receptio a Contrario yang merupakan salah satu bentuk perlawanan sebagai bukti bahwa syariat Islam masih eksis di Indonesia. Ada dua masalah yang sangat mempengaruhi penerapan hukum Islam di Indonesia. Makalah ini menjelaskan masalah penerapan hukum Islam di Indonesia. Pembahasan ini difokuskan pada masuknya hukum Barat ke Indonesia dan kontaknya dengan hukum adat yang sudah berlaku di masyarakat Indonesia, dan yang kedua adalah pengaruh politik dan budaya masyarakat. Makalah ini merupakan hasil penelitian literatur.
\end{abstract}

Kata Kunci: Penyusunan, Hukum Islam, Indonesia

\begin{abstract}
The assembling of Islamic law in Indonesia has faced obstacles since it began to enter Western law into Indonesia. So that several legal theories were born in response to the friction between Western law and Islamic law. The recipe theory is one of the Dutch strategies to discredit and reduce Islamic law that has prevailed in Indonesia. Then, came the theory of Exept law Exit and Receptio a Contrario which is one form of resistance as proof that Islamic law still exists in Indonesia. There are two problems that greatly influence the application of Islamic law in Indonesia. This paper explains the problem of applying Islamic law in Indonesia. This discussion is focused on the entry of Western law into Indonesia and its contact with customary law that already applies to Indonesian society, and the second is the influence of political and cultural society. This paper is the result of literature research.
\end{abstract}

Keywords:The assembling, Islamic law, Indonesia 


\section{A. PENDAHULUAN}

Dilihat dari sejarahnya sistem hukum di Indonesia bersifat majemuk. Hal ini dikarenakan sistem hukum di Indonesia mempunyai pola tersendiri. Sistem hukum yang selama ini berlaku di Indonesia adalah sistem hukum adat, sistem hukum Islam, dan sistem hukum barat. Sistem hukum adat adalah sistem hukum yang sudah sangat lama dikenal dan berlaku di Indonesia, sistem hukum ini dikenal jauh sebelum Islam datang di Indonesia. Sistem hukum Islam mulai ada bersamaan dengan datangnya orang Islam di kepulauan Indonesia. Menurut sejarah Islam datang ke Nusantara sekitar abad ketujuh masehi. Namun ada Pendapat lain yang menyatakan bahwa Islam baru sampai ke Indonesia sekitar abad ke13 masehi ${ }^{1}$. Sedangkan hukum barat mulai dikenalkan pemerintah Belanda pada tahun 1602 melalui VOC ketika menguasai perdagangan di Indonesia. Pada mulanya, hukum barat hanya berlaku umtuk orang Eropa yang bermukim di Indonesia, namun dengan berjalannya waktu dalam bidang perekonomian dan perdagangan hukum tersebut diberlakukan pula untuk orang Indonesia ${ }^{2}$.

Pada tahun 1945 hukum Islam di Indonesia mulai memunculkan identitasnya dengan lahirnya perumusan dasar Negara yang tercantum dalam piagam Jakarta. Rumusan Dasar Negara Indonesia tersebut salah satunya adalah "Negara yang berasaskan Ketuhanan dengan menjalankan Syariat Islam bagi pemeluknya". Tetapi atas alasan kemajemukan Agama di Indonesia rumusan dasar dalam Piagam Jakarta terebut diganti

\footnotetext{
${ }^{1}$ Hossein, Sejarah Perkembangan Islam di Indonesia, Pustaka Antarkota, Jakarta, 1961, .114.

2 Abdul Wahid \& Musthofa, Hukum Islam Kontemporer, Sinar Grafika, Jakarta, 2013, .115.
}

dengan "Ketuhanan yang Maha Esa". Hazairin berpendapat bahwa perubahan salah satu rumusan dasar Negara dalam piagam Jakarta tersebut memuat aturan hukum yang diatur dalam pasal 29 ayat (1) UUD 1945 bahwa Negara Republik Indonesia berdasarkan atas Ketuhanan Yang Maha Esa. Hal ini dapat ditafsirkan antara lain: "Pemeluk Agama Islam wajib menjalankan ajaran syariat Islam, sama halnya agama-agama lainnya wajib menjalankan agamanya". Sedangkan tafsir lainnya menyatakan "Ajaran Agama tidak memerlukan bantuan kekuasaan Negara untuk menjalankannya sebab menjadi kewajiban pribadi terhadap Agamanya masing-masing". 3

Berdasarkan Ihwal (problem) penerapan Hukum Islam di Indonesia sebagaimana gambaran diatas, akhirnya hukum Islam dan kekuatannya diakomodasi oleh Pancasila dan UUD 1945. Diantaranya adalah berlakunya Undang-Undang nomor 1 tahun 1974 mengenai hukum perkawinan Islam. Selain itu, lahir komplikasi Hukum Islam yang berfungsi sebagai pedoman bagi Hakim di Peradilan Agama. Indonesia sebagai Negara yang mempunyai Agama majemuk juga merupakan Negara Hukum, sehingga untuk menguatkan tatanan kehidupan berbangsa dan bernegara Indonesia juga memerlukan suatu aturan hukum. Dalam rangka menguatkan tatanan hukum juga diperlukan suatu sistem yang mengatur hukum tersebut ${ }^{4}$. Mix law merupakan sistem hukum yang digunakan di Indonesia, yaitu berlakunya hukum campuran. Sistem

3 Ali Zainudin, Hukum Islam Pengantar Ilmu Hukum Islam di Indonesia, Sinar Grafika, Jakarta, 2006, .85.

${ }^{4}$ Achmad, Menguak Teori Hukum dan Teori Peradilan Termasuk Interpretasi Undang-Undang, Kencana, Jakarta, 2009, .204. 
hukum ini, selain berlakunya hukum perundang-undangan, juga berlaku hukum lain yang diakui dalam Konstitusi Negara Indonesia yaitu UUD 1945 yang telah mengatur kehidupan berbangsa dan bernegara. Selain itu, Konstitusi Negara Indonesia juga mengatur kehidupan beragama, hal ini tertera dalam pembukaan UUD 1945 alinea keempat yang menyatakan "Ketuhanan Yang Maha Esa”. Pernyataan ini mengandung pengakuan terhadap keagamaan. Sehingga dapat dibenarkan jika Islam adalah salah satu agama yang diakui di indonesia. Juga diakui eksistensinya sebagai Agama yang resmi dan hukum Islam sebagai hukum yang berlaku bagi pemeluknya di Indonesia. Dari pemaparan diatas dapat disimpulkan bahwa sebenarnya Hukum Islam telah dikenal dan berlaku sejak pertama kali Islam datang ke Indonesia.

\section{B. HASIL PENELITIAN DAN PEMBAHASAN}

Ihwal penerapan Hukum Islam di Indonesia yang pertama adalah sebab masuknya hukum barat ke Indonesia dan ketersinggungannya dengan hukum adat yang ada., sedangkan yang kedua adalah pengaruh politik dan kebudayaan masyarakat. Kedua ihwal (problem) tersebut penulis uraikan sebagaimana berikut:

\section{a. Masuknya Hukum Barat dan Ketersinggungannya dengan Hukum Adat}

Saat pertama kali Belanda datang ke Indonesia, masyarakatnya menganut Hukum Agama seperti Nasrani, Hindu, Budha. Selain itu hukum adat juga berlaku pada masyarakatnya ${ }^{5}$. Sebagai penjajah,

5 Abdul Wahid \&musthofa, Hukum Islam Kontemporer, Sinar Grafika, Jakarta, 2013. .143.
Belanda yang pada dasarnya menganut agama Kristen Protestan mau tidak mau harus bersentuhan dengan permasalahan hukum yang ada pada Negara jajahannya. Ketika Belanda masuk ke Indonesia, di masyarakat berlaku hukum Adat dan hukum Agama bagi pemeluknya. Setelah itu Belanda memberlakukan hukum barat melalui VOC bagi orang Indonesia untuk mengatur perekonomian pada umumnya ${ }^{6}$. Sejak saat itulah mulai terjadinya gesekan antara hukum telah ada dan yang berlaku di Indonesia dengan Hukum Barat. Untuk melancarkan rencananya, Belanda melemahkan eksistensi hukum Islam dan hukum Adat yang sejatinya telah lama berlaku di Indonesia. Sedemikian hingga muncullah teori-teori hukum salah satunya teori Reciptie sebagai rekayasa belanda untuk melemahkan hukum Islam. Kemudian muncullah teori hukum Reciptie Exit dan Reciptio A Contrario sebagai cara dari para pengamat hukum di Indonesia untuk menentang teori Reciptie.

Teori Reciptie merupakan teori hukum yang dicetuskan oleh C. Snouck Hurgronje seorang penasehat pemerintah Hindia Belanda mengenai kajian-kajian Islam di Wilayah Jajahan Belanda. Kemudian teori ini disempurnakan oleh C. Van Vollen dan Betrand Ter Haar Bzn untuk diterapkan di Indonesia. Menurut penganut teori Reciptie ini hukum Islam tidak dianggap sebagai hukum jika bertolak belakang dengan hukum Adat, dikarenakan hukum Adat yang menentukan berlaku dan tidaknya hukum Islam ${ }^{7}$. Salah satu contoh efek yang ditimbulkan dari teori ini, yaitu: Hukum Islam yang bersumber dari Al Qur'an dan Hadist, hanya beberapa

${ }^{6}$ Abdul Wahid \&musthofa, Hukum Islam Kontemporer, 115.

Ali Zainudin, Sosiologi Hukum, Sinar Grafika, Jakarta, 2016, .82 
yang bisa dilaksanakan oleh umat Islam dan diakui oleh Negara. Sedangkan hukum pidana yang bersumber dari Al Qur'an dan Hadist tidak memiliki tempat untuk dilaksanakan sebagai putusan hakim apabila hukum yang dimaksud tidak termasuk dalam undang-undang di Indonesia. Selain itu, hukum Islam juga harus diresmikan menjadi Undang-Undang terlebih dahulu kemudian baru bisa berlaku bagi pemeluk-pemeluknya secara formal. Namun jika hukum Islam telah diundang-undangkan, maka pemeluk Islam berhak memilih sesuai keinginannya, yaitu bisa memilih antara hukum Islam atau hukum Pengadilan Negeri ${ }^{8}$.

Sedangkan teori Receptie Exit adalah teori yang digagas Hazairin yang dikembangkan oleh muridmuridnya ${ }^{9}$. Teori ini muncul sebagai penolakan atas teori Receptie, bahwa teori Receptie harus dihapus dari teori hukum Indonesia dikarenakan bertentangan denngan UUD 1945 dan Al Qur'an serta As Sunnah. Hazairin berpendapat bahwa hukum Islam itu bagi rakyat yang beragama Islam dilaksanakannya sebagai bagian dari perkara imannya ${ }^{10}$. Dan secara lebih lanjut Hazairin mengemukakan bahwa teori Receptie digagas oleh pemerintah Belanda untuk menghalangi keberadaan hukum Islam di Indonesia ${ }^{11}$. Teori Receptie bagi ahli hukum di Indonesia telah mendarah daging, sebab mereka adalah didikan Belanda. Sedangkan menurut pandangan Hazairin Teori Receptie $\underset{9}{\text { Grafika, }} .82$

${ }^{8}$ Ali Zainuddin, Sosiologi Hukum, Sinar

9 Ali Zainuddin, Islam Tekstual dan Kontekstual Suatu Kajian Aqidah Syariah dan Akhlak, Yayasan Al-Ahkam, Makasar, 1998, .41.

10 Hazairin, Tujuh Serangkai Tentang Hukum, Tintamas Indonesia, Jakarta, 1974, .101.

${ }^{11}$ Hazairin, Hukum Kekeluargaan Nasional, Tintamas Indonesia, Jakarta, 1982, .7. tidak jauh berbeda seperti teori iblis, sebab teori tersebut menentang keimanan seorang muslim. Kemudian Hazairin menyimpulkan bahwa Teori Receptie yang ditetapkan dalam pasal 134 ayat 2 Indische Staaisregeling sebenarnya sudah musnah sejak UUD 1945 diberlakukan kembali sebagai Konstitusi resmi di Indonesia ${ }^{12}$. Teori Receptie Exit memandang berlakunya Hukum Islam tidak harus bergantung kepada Hukum Adat. Buktinya adalah dengan berlakunya UU No. 1 Tahun 1974 mengenai Perkawinan. UU tersebut menerapkan Hukum Islam bagi orang Islam dalam perkara perkawinan. Selain itu dikuatkan dengan adanya Pasal 2 ayat (1), UU No. 7 Tahun 1989 tentang Peradilan Agama.

Adapun teori Receptio A Contrario adalah teori hukum yang dicetuskan oleh Sayuti Thalib yang termasuk pengembangan dari teori Receptie Exit. Masyarakat Aceh menggunakan Hukum Islam dalam menyelesaikan persoalan perkawinan dan kewarisan, jika ada ketentuan Hukum Adat didalamnya maka boleh dipakai dengan ketentuan syarat Hukum Adat tersebut tidak boleh bertentangan dengan Hukum Islam ${ }^{13}$. Contoh lain seperti Suku di Bugis Sulawesi Selatan. Suku ini awalnya menggunakan Hukum Adat dalam praktik kewarisan yaitu pembagian yang sama besar antara anak lakilaki dan anak perempuan. Namun setelah memeluk Agama Islam, Hukum Adat tentang kewarisan (1:1) ditinggalkan dan menggunakan cara Hukum Islam yaitu satu bagian warisam seorang anak lelaki sama dengan dua kali bagian warisan

\footnotetext{
${ }^{12}$ Hazairin, Hukum Kekeluargaan Nasional, Tintamas Indonesia, ,7.

13 Abdul Wahid \&musthofa, Hukum Islam Kontemporer, Sinar Grafika, Jakarta, 2013. .150.
} 
seorang anak perempuan. Selanjutnya Suku Kaili di Sulawesi Tengah, menurut Hukum Adat pasangan calon pengantin yang ingin menikah salah satu syaratnya adalah meminta Izin kepada Dewan Adat untuk dipercikkan air dari sumber mata air yang bersih. Namun setelah memeluk Islam tatacara Adat tersebut di tinggalkan, kemudian menggunakan tatacara yang sesuai dengan Hukum Islam $^{14}$. Selain beberapa contoh di atas, terdapat ungkapan-ungkapan yang menegaskan tentang hubungan Hukum Adat yang menghormati Hukum Islam. Misalnya Suku Aceh memiliki pepatah "Adek dab Syara' sanda menyanda, Syara' mengato Adek memakai", maksudnya adalah hubungan antara adat dan Hukum Islam sangat erat, saling kuat menguatkan, Hukum Islam menentukan Adat melaksanakan. Pepatah lain dari salah satu suku di Sumatera mengatakan "Adat Bersendi Syara', Syara' bersendi Kitabullah", maksudnya adalah sumber dari Hukum Adat adalah Hukum Islam, sedangkan Hukum Islam bersumber pada Al Qur'an ${ }^{15}$. Dalam menyikapi persinggungan antara Teori Receptie dengan Teori Receptie Exit, Hooker melakukan suatu penelitian pada beberapa wilayah di Indonesia, sehingga melahirkan Teori Sinkritisme. Menurut teori ini antara Hukum Adat dan Hukum Islam tidaklah saling menyisihkan, masingmasing hukum tersebut memiliki daya ikat yang sama atau sederajat, sehingga masing-masing hukum tersebut mampu menciptakan kekuatan agar masyarakat menyadari

14 Ali Zainudin, Hukum Islam Pengantar Ilmu Hukum Islam di Indonesia, Sinar Grafika, Jakarta, 2006, .83.

15 Ali Zainudin, Hukum Islam Pengantar Ilmu Hukum Islam di Indonesia, .83. untuk melaksanakannya. Namun, kesamaan derajat antara dua hukum tersebut terkadang tidak searah, sehingga adakalanya mengalami konflik, seperti persinggungan antara Hukum Adat dengan Hukum Islam di Minangkabau. Menurut teori Sinkritisme ini, berlakunya Hukum Adat maupun Hukum Islam dikarenakan kesadaran masyarakat untuk melaksanakannya bukan karena mana yang lebih dominan salahsatu dari kedua sistem hukum tersebut.

\section{b. Pengaruh politik dan}

\section{Kebudayaan Masyarakat.}

Problem diterapkannya Hukum Islam di Indonesia memiliki dua pengaruh yaitu politik dan Kebudayaan masyarakat. Piagam Jakarta yang merumuskan sila Ketuhanan yaitu: "dengan kewajiban menjalankan Syariat Islam bagi para pemeluknya". Mendapat reaksi dari berberapa masyarakat yang tidak setuju dengan rumusan tersebut sehingga mereka hendak memisahkan diri dari Negara Kesatuan Republik Indonesia. Sebab rumusan sila Ketuhanan Pada Piagam Jakarta memberikan keistimewaan kepada salahsatu Agama, sedangkan keadaan di Indonesia memiliki Agama yang plural. Pengesahan Hukum Islam pada awal persiapan kemerdekaan menimbulkan respon dari Agama lain sebagai efek politik dari pembentukan Negara Kesatuan Republik Indonesia.

Pengesahan Hukum Islam diatas kemajemukan yang ada di Indonesia juga akan menjadikan efek pandangan politik. Pandangan politik ini terjadi pada saat pembentukan Rancangan Undang-Undang Peradilan Agama atau RUUPA. Rancangan Undang-Undang ini membicarakan tentang kewenangan, susunan, dan acara. Disamping itu, kekuasaan RUUPA hanya dibatasi untuk masalah perkawinan, 
pembagian warisan, sedekah, dan wakaf yang termasuk dalam bagian ibadah umat Islam. Akan tetapi, rancangan ini menimbulkan perdebatan. Perdebatan ini terjadi diberbagai halaman opini dan berita wawancara $^{16}$. Perdebatan tersebut diantaranya adalah tanggapan dan reaksi politis Frans Magis Suseno. Inti dari reaksi tersebut adalah jika Negara memberikan sebagian dari peradilannya kepada pihak bukan Negara, seperti Agama, itu artinya Negara patuh atas hukum yang bukan termasuk buatannya sendiri dan juga memberikan kedaulatannya kepada pihak lain. Itu termasuk pengurangan dari kedaulatan suatu Negara. reaksi tersebut juga mengemukakan bahwa jika ada Peradilan Agama disamping adanya peradilan Negara, lalu bagaimana kesatuan peradilan di Indonesia bisa terjamin? Padahal salah satu unsur Konstitutif dari suatu bangsa adalah kesatuan peradilan. Jelas saja reaksi tersebut memberi semacam respon politik yang sangat menyita perhatian untuk dipertimbangkan. Respon tersebut mencoba membujuk para tokoh Islam untuk memikirkan kembali kekhawatiran kelompok Agama lain yang tentu saja wajar dan harus diberikan tempat.

Reaksi politik seperti di atas sangat wajar, itu dikarenakan timbulnya kehawatiran dari Agama lain apabila konsep Piagam Jakarta benar-benar akan dijadikan sebagai landasan utama di Indonesia. Serta kekhawatiran lainnya adalah apabila muncul percobaan didirikan Negara Islam. Akibatnya timbul permasuatu masalah yang tiada ujungnya. Kemudian Presiden Soekarno menawarkan sebuah solusi, yaitu

16 Abdul Wahid \&musthofa, Hukum Islam Kontemporer, 150. mengembalikan UUD $1945^{17}$.

Masalah kebudayaan juga menjadi kendala dalam diterapkannya Hukum Islam di Indonesia. Menurut sejarah, hukum yang berlaku di Indonesia adalah hukum Islam yang menundukkan hukum Adat didalamnya. Kemudian Belanda datang ke Indonesia dan mengenalkan sistem Hukum Barat, sehingga ada dualisme sistem hukum yang saling berhadapan yaitu sistem Hukum Islam dan sistem Hukum Barat. Kemudian dengan bantuan para ahli budaya, pemerintah Belanda berhasil mengangkat kedudukan adat istiadat masyarakat lokal yang dinamakan sebagai sistem hukum Adat dan mempertimbangkannya dengan sistem Hukum Islam, serta menguatkan kedudukan praktik sistem hukum Barat. Sedemikian hingga pada masa Belanda system hokum di Indonesia memiliki beberapa tingkatan,yaitu Hukum Barat sebagai hukum tingkat pertama, Hukum Adat berada pada tingkat kedua, sedangkan Hukum Islam berada pada tingkat ketiga. Hal ini mengakibatkan Hukum Islam selalu diletakkan dalam posisi yang berlawanan dengan Hukum Barat dan Hukum Adat. Sehingga setelah kemerdekaan Indonesia hanya Hukum Barat dan Hukum Baratlah yang dimasukkan sebagai Hukum Nasional, sedangkan Hukum Islam masih tetap menjadi yang ketiga dikarenakan dianggap tidak terlalu menguntungkan bagi konteks sistem Hukum Nasional. Hingga saat ini, masih ada masalah besar dilingkungan umat Islam dalam memahami apa itu hukum Nasional yang berbentuk undang undang resmi. Misalnya UU No. 1 tahun 1974, yang berisi cerminan dari

17 Abdul Wahid \&musthofa, Hukum Islam Kontemporer,. .129-130. 
hukum fikih yang masih sulit untuk diterima dan di anggap sebagai hukum Islam. Hal tersebut karena hukum perkawinan yang disebut dalam undang-undang ini tidak disebut Hukum Perkawinan Islam, dan ada perbedaan pula antara ketentuan undang-undang dengan hukum fikih tradisional. Maka dari itu, keragaman hukum fikih dan keragaman pendapat para ulama di Indonesia, berdampak pada dipertentangkannya beberapa undang-undang perkawinan.

Salah satu contoh perbedaan tanggapan mengenai keberadaan Hukum Islam di Indonesia adalah ketika akan diterapkannya undangundang tentang Peradilan Agama tahun 1988-1989, ada salah satu Organisasi masyarakat Islam yang memberi tim pengkajian RUU sebuah surat resmi, untuk merekomendasikan usul bahwa penetapan putusan perkawinan adalah kewenangan dari Peradilan Agama. Inti dari surat tersebut adalah kewenangan Peradilan Agama hanya sebatas pada administrasi saja, sedangkan jatuhnya talak tidak harus dilakukan di depan Hakim. Hal tersebut dikarenakan seperti itulah hal yang tercantum dalam aturan hukum Islam $^{18}$. Kendala kebudayaan juga datang dari golongan pendukung sistem Hukum Islam sendiri, salah satunya yaitu masih adanya anggapan bahwa Hukum Islam merupakan hukum yang final oleh karenanya tidak perlu dikembangkan lagi. Salah satu contohnya adalah pasal RUU Perkawinan yang membahas tentang pertunangan, pasal tersebut mendapatkan kritikan dari para ulama. Bunyi pasal tersebut adalah "bila pertunangan itu mengakibatkan

${ }^{18}$ Abdul Wahid \&musthofa, Hukum Islam Kontemporer,..139. kehamilan, maka pihak pria diharuskan kawin dengan wanita itu, jika disetujui oleh pihak wanita", pasal ini mendapatkan keritik dikarenakan mengandung persepsi bahwa pertunangan menjadi syarat bolehnya hubungan intim sebelum melaksanakan akad nikah. Fenomena di atas merupakan salah satu perbedaan pandangan kebudayaan fikih yang melemahkan keberadaan Hukum Islam di Indonesia.

\section{Kendala Penerapan Hukum Islam diIndonesia}

Sejak awal kemerdekaan rencana diterapkannya Hukum Islam memang mendapat berbagai macam hambatan yang cukup mempengaruhinya. Terdapat dua permasalahan, yakni:

Pertama; Hukum Islam menjadi penengah antara Paradigma Agama dengan Paradigma Negara. Menurut Paradigma Agama menerapkan Hukum Islam menjadi bagian terpenting dalam melaksanakan totalitas keagamaan, sebab keberadaannya diyakini sebagai Wahyu yang wajib untuk dilaksanakan. Sedangkan pada paradigma Negara menerapkan Hukum Islam termasuk suatu hal yang kurang tepat karena mengingat bahwa Indonesia termasuk Negara dengan Agama majemuk. sehingga untuk mempertahankan kemajemukan tersebut, Negara terpaksa mengurangi Hukum Islam dan beberapa instrumen keIslaman lainnya. Hal ini tidak lain tidak bukan hanya untuk mempertahankan kelompok Agama laim agar tetap bergabung dengan Indonesia. Agar Agama lain tidak merasa cemburu, maka Negara harus bersikap adil, tidak hanya memihak kepada satu agama.

Kedua; Negara Indonesia termasuk Negara dengan agama majemuk, jika Negara mengkhususkan salahsatu agama 
saja, tentu menimbulkan kecemburuan dan keterasingan dari agama lain. Negara berkewajiban mereduksi Hukum Islam tujuannya agar meminimalisir kecemburuan dari agama yang lainnya. Hal ini dilakukan hanya untuk menjaga kemajemukan Agama di Indonesia.

Berdasarkan kemajemukan Agama, diterapkannya Hukum Islam adalah salah satu ancaman untuk Agama lain, sehingga satu-satunya solusi adalah dengan mengembalikan UUD 1945 dan pancasila untuk memberi perlindungan hukum terhadap kemajemukan Agama tersebut. Selain itu, untuk tetap menjaga persatuan dan kesatuan Indonesia supaya tidak terjadi perpecahan.

\section{Kesimpulan}

Berdasarkan pembahasan diatas, dapat disimpulkan bahwa:

1. Hukum Islam sudah dikenal dan berlaku sejak pertama kali masuk ke Indonesia.

2. Terdapat beberapa ihwal (problem) yang muncul seiring dengan diterapkannya Hukum Islam di Indonesia, yaitu: a) masuknya hukum barat ke Indonesia, hukum yang dibawa oleh penjajah Belanda dan mulai dikenalkan oleh VOC untuk mengatur perekonomian di daerah jajahannya b) ketersinggungannya dengan hukum adat, hukum yang telah berlaku di masyarakat Indonesia jauh sebelum Islam datang ke Indonesia c) pengaruh politik Indonesia, yang terjadi ketika pembentukan Rancangan Undang-Undang Peradilan Agama d) pengaruh kebudayaan Indonesia.

3. Hukum Islam sebenarnya berada di wilayah Negara sekaligus berada di wilayah agara, hal itu menyebabkan Hukum Islam sangat sulit untuk diterapkan di Indonesia.

4. Kemajemukan Agama juga menjadi sebab sulitnya Hukum Islam diterapkan di Indonesia. Apabila penerapan Hukum Islam masih tetap dilakukan maka akan timbul ancaman bagi Agama lainnya. Maka solusi yang tepat adalah kembali kepada UUD 1945 dan pancasila, untuk perlindungan hukum terhadap kemajemukan Agama di Indonesia.

\section{Daftar Pustaka}

Abdullah, Ghani. 2002. pengantar Kompilasi hukum Islam dalam tata hukum Indonesia. Jakarta: Gema Insani Press.

Bakry, Kasman. 2018. "The Implementation Of Islamic Law At The Early Spread Of Islam In Indonesian Archipelago". Jurnal Ilmiah Al-Syari'ah. Vol.16, No.02. http://dx.doi.org/10.30984/jis.v16i2.68 5. 15 Maret 2020.

Hazairin. 1960. Hendak Kemana Hukum Islam. Jakarta: Tintamas.

Hazairin. 1974. Tujuh Serangkai Tentang Hukum. Jakarta: Tintamas Indonesia.

Hazairin. 1982. Hukum Kekeluargaan Nasional (Cet. Ke 3). Jakarta: Tintamas Indonesia.

Hossein, D. 1961. Sejarah Perkembangan Islam di Indonesia. Jakrrta: Pustaka antarkota.

Jaih Mubarok, 2015. Pembaharuan Hukum Perkawinan di Indonesia. Bandung: Simbiosa Rekatama Media.

Shomad, abdul. 2017. Hukum Islam:Penormaan Prinsip Syariah dalam Hukum Indonesia. Jakarta: Kencana. 
Usman, S. 2001. Hukum Islam, Asas-asas dan Pengantar Studi Hukum Islam dalam Tata Hukum di Indonesia. Jakarta: Gaya Media Pratama.

Wahid, Musthofa. 2013. Hukum Islam Kontemporer. Jakarta: Sinar Grafika.

Yanlua, Mohdar. Februari 2015. "Prospective Islamic Law In Indonesia". Journal of Humanity Print. Vol.03, No.01, http://media.neliti.com. 01 Maret 2020.

Yasa, Ahmad. September 2015. "The
Development Of Indonesian Islamic Law: A Historical Overview". Journal Of Indonesian Islam. Vol.09, No.01. http://jiis.uinsby.ac.id. 03 Maret 2020.

Zainuddin, Ali. 1998. Islam Tekstual dan Kontekstual Suatu Kajian Aqidah, Syariah dan Akhlak. Makasar: Yayasan al-Ahkam.

Zainuddin, Ali. 2006. Hukum Islam Pengantar Ilmu Hukum Islam di Indonesia. Jakarta: Sinar Grafika.

Zainuddin, Ali. 2016. Sosiologi Hukum. Jakarta: Sinar Grafika. 